\title{
HEAT-TRANSFER ENHANCEMENT OF NANOFLUIDS IN A CAR RADIATOR
}

\author{
IZBOLJŠANJE PRENOSA TOPLOTE NANOTEKOČIN V \\ AVTOMOBILSKEM RADIATORJU
}

\author{
Thangasamy Ganesan', Pauldurai Seeni Kannan² \\ ${ }^{1}$ Department of Mechanical Engineering, AR College of Engineering \& Technology, Kadayam, Tamilnadu 627 423, India \\ ${ }^{2}$ Department of Mechanical Engineering, AAA College of Engineering and Technology, Sivakasi, Tamilnadu 626 123, India \\ ganesanjoshi2012@gmail.com
}

Prejem rokopisa - received: 2017-10-07; sprejem za objavo - accepted for publication: 2018-02-22

doi: $10.17222 / \mathrm{mit} .2017 .171$

\begin{abstract}
In recent times, enhancing the efficiency of automobiles has become very important. As part of this effort, increasing the efficiency of the heat transfer in the radiator of an automobile is also crucial. The present approach involves an addition of nanoparticles to the cooling liquid. Most of the current results were obtained using a few types of nanoparticles. Only a limited amount of work involved hybrid nanofluids including several types of nanoparticles. Multi-walled carbon nanotubes (MWCNT) were used along with aluminium-oxide nanoparticles to form a nanofluid with the base fluid (ethylene glycol (EG) + distilled water (DW) - 1:1 ratio) having volume concentrations of $(0.03,0.06,0.09$ and 0.12$) \%$. The characterization of the nanoparticles was carried out. The experiments were carried out at inlet temperatures of $40-75^{\circ} \mathrm{C}$, with increments of $5{ }^{\circ} \mathrm{C}$. The volume flow rate was varied from $0.6 \mathrm{~m}^{3} / \mathrm{h}$ to $0.96 \mathrm{~m}^{3} / \mathrm{h}$, with increments of $0.12 \mathrm{~m}^{3} / \mathrm{h}$. An increase in the heat transfer of $35 \%$ was achieved.
\end{abstract}

Keywords: computational fluid dynamics, nanofluids, alumina, multi-walled carbon nanotubes

V zadnjem času je postalo zelo pomembno povečanje zmogljivosti avtomobilov, hkrati s tem pa tudi povečanje učinkovitosti prenosa toplote $\mathrm{v}$ avtomobilskih radiatorjih. V prispevku so avtorji dodali nanodelce $\mathrm{v}$ hladilno sredstvo (kapljevino). Večina podanih rezultatov se nanaša na uporabo nekaj različnih vrst nanodelcev. Delno pa so avtorji raziskovali tudi hibridna hladilna sredstva oziroma vpliv istočasnega dodatka več različnih vrst nanodelcev. Uporabili so dodatek večstenskih ogljikovih nanocevk (MWCNT; angl.: Multi Walled Carbon Nano Tubes) v kombinaciji z nanodelci Al oksida k osnovnemu hladilnemu sredstvu (Etilen Glikol (EG) + destilirana voda (DW) - v razmerju 1:1) v volumskih koncentracijah $(0,03,0,06,0,09$ and 0,12$) \%$. Izvedli so karakterizacijo nanodelcev. Preizkuse so izvajali pri vstopnih temperaturah hladilnega sredstva od $40{ }^{\circ} \mathrm{C}$ do $75{ }^{\circ} \mathrm{C}$ v korakih po $5{ }^{\circ} \mathrm{C}$. Hitrost volumskega pretoka je varirala od $0,6 \mathrm{~m}^{3} / \mathrm{h}$ do $0,96 \mathrm{~m}^{3} / \mathrm{h} \mathrm{v}$ korakih po $0,12 \mathrm{~m}^{3} / \mathrm{h}$. Dosegli so povečanje prenosa toplote do $35 \%$.

Ključne besede: računalniška dinamika tekočin (kapljevin in plinov), nanotekočine, aluminijev oksid, večstenske ogljikove nanocevke

\section{INTRODUCTION}

Only a part of the heat energy produced with combustion is converted to the mechanical energy to power the automobiles while the remaining energy is rejected and unutilized. A part of the energy is removed by the cooling water surrounding the engine and then taken to the radiator while the heat is released into the atmosphere. If effective cooling is not done, the efficiency of the engine can be reduced and, in extreme cases, engine may be damaged by overheating. The cooling system normally consists of a cooling medium surrounding the engine cylinder, a pump allowing the circulation of the cooling medium, a radiator with a cooling fan and a thermostat. In the present work, an attempt to improve the effectiveness of the heat transfer in the radiator was made. With the advances made in the field of nanotechnology, we now have nanoparticles, which can be mixed with the fluid to form a homogeneous mixture. These mixtures are called nanofluids and they have better thermal properties. They enhance the heat transfer even with a low concentration of nanoparticles. The papers published so far indicate improvement in the heat transfer due to single nanoparticles. Further research can be done using hybrid nanofluids, which are mixtures of more than one type of nanoparticles. It is expected that hybrid nanofluids will improve the heat transfer.

\section{LITERATURE SURVEY}

A brief survey of the work done so far is presented below.

K. S Suganthi et al. ${ }^{1}$ prepared a nanofluid using a spherical $\mathrm{ZnO}$ by mixing it with water and propylene glycol (PG). The heat-absorption capacity of their nanofluid was compared with that of the solution of just water and PG. The nanofluid showed a higher heat absorption capacity than the solution of water and PG. The nanofluid showed an increase of $16 \%$ in the case of heat transfer under indicator conditions with $2 \%$ volume of $\mathrm{ZnO}$ of $70 \mathrm{~nm}$. B. Ilhan et al. ${ }^{2}$ used hexagonal boron nitride $(\mathrm{HBN})$ to make a nanofluid using a volume con- 
centration of $0.03-0.3 \%$ to make nano sodium dodecyl sulphate (SDS) and polyvinyl pyrrolidon was used as the surfactant. The HBN nanofluild had a higher thermal conductivity compared to the base fluid. M. A. A. Behabadi et al. ${ }^{3}$ conducted experiments using multi-walled carbon nanotubes (MWCNT). They were mixed with water with weight concentrations of $0.05,0.1$ and 0.2. The MWCNT nanofluid showed an enhanced heat-transfer rate. The pressure drop in this case was higher than that of the base fluid. W. H. Azmi et al. ${ }^{4}$ compared the performance of a water-based nanofluid and ethyleneglycol water-based nanofluid. The water-based nanofluid showed a higher heat-transfer rate. M. B. Bigdeli et al. ${ }^{5}$ carried out a study of thermophysical properties of a nanofluid. The study shows the nanofluid having better thermal properties than the base fluids. However, the details of the concentration and size of the nanoparticles were not reported. M. Tamizi et al. ${ }^{6}$ studied the thermophysical properties of a nanofluid with different volume fractions. It was shown that the heat-transfer rate was higher for a higher volume fraction. S. Suresh et al. ${ }^{7}$ used a hybrid nanofluid in their study. The nanofluid was made with the nanoparticles of aluminium oxide and copper. The experiment showed an improvement of $25 \%$ for the heat transfer compared to the base fluid. D. Madhesh et al. ${ }^{8}$ used copper and titanium nanoparticles with volume concentrations varying from $0.1 \%$ to $1 \%$ in a radiator and heat-transfer rates increased by up to $48.5 \%$ were attained. N. Bozorgan et al. ${ }^{9}$ conducted a numerical investigation of $\mathrm{Al}_{2} \mathrm{O}_{3}$ nanoparticles with water as the base fluid using empirical relations to determine the properties such as density, viscosity, specific heat and thermal conductivity. G. Huminic et al. ${ }^{10}$ also studied the thermal properties of a nanofluid and found the heattransfer rate increasing with an addition of nanoparticles.

\section{EXPERIMENTAL PART}

Figure 1 shows a diagram of the experimental set-up and Figure 2 includes a photograph of the set-up.

The set-up included the radiator from a Maruthi Alto car. The engine had the power of 85 BHP. There were also the cooling fan, the water tank, the heater, and the control for the heater used to maintain the temperature of the inlet of the water, which was constant for the components in the set-up. Instruments for measuring the temperature of the water at the inlet and outlet were provided. Two additional thermocouples were provided to measure the temperature of the air, flowing across the radiator. They were fixed to the air inlet and outlet of the radiator.

A gate valve was provided to regulate the flow of the water through the radiator. Three heater controllers were provided to heat the water to be sent to the radiator to the steady state temperature of the inlet. The radiator was placed inside a duct and a fan was used to provide the flow at two different speeds. Experiments were carried out for different flow rates of $0.6 \mathrm{~m}^{3} / \mathrm{h}$ and $0.96 \mathrm{~m}^{3} / \mathrm{h}$

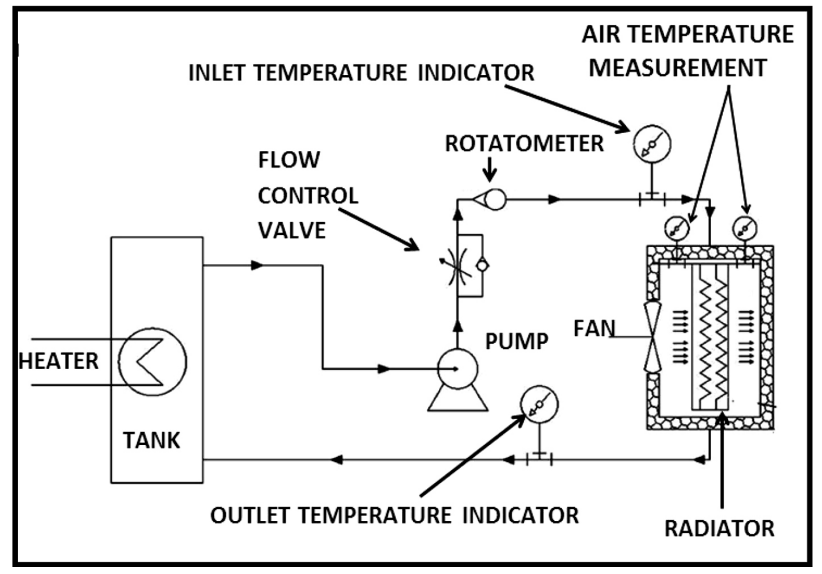

Figure 1: Circuit diagram of the experimental set-up

Table 1: Experimental set-up specifications

\begin{tabular}{|c|c|}
\hline Radiator & $\begin{array}{l}\text { Width: } 370 \mathrm{~mm} \text {; Height: } 400 \mathrm{~mm} \text {; Tube size: } 20 \\
\times 2 \mathrm{~mm} \text {; Fin thickness: } 1 \mathrm{~mm} \text {; Fin pitch: } 1 \mathrm{~mm}\end{array}$ \\
\hline Tank & $\begin{array}{l}\text { Capacity: } 14 \text { l; Material: stainless steel; } \\
\text { Diameter: } 260 \mathrm{~mm} \text {; Height: } 300 \mathrm{~mm}\end{array}$ \\
\hline Heater & $\begin{array}{l}\text { Type: Epson; Number of heaters: } 3 \text {; Power: } \\
2 \mathrm{~kW} \text {; Thermostat: range of } 0-75^{\circ} \mathrm{C} \text { (Girsheg); } \\
\text { Accuracy: } \pm 0.5{ }^{\circ} \mathrm{C}\end{array}$ \\
\hline Pump & $\begin{array}{l}\text { Made by CRI; Capacity: } 0.5 \mathrm{hp} \text {; Speed: } \\
2800 \mathrm{~min}^{-1} \text {; Water capacity: } 1080 \mathrm{l} / \mathrm{hr}\end{array}$ \\
\hline $\begin{array}{l}\text { Thermo- } \\
\text { meter }\end{array}$ & $\begin{array}{l}\text { Type: digital; Make: Nanotech; Range: } \\
0-400^{\circ} \mathrm{C} \text {; Accuracy: } \pm 0.5^{\circ} \mathrm{C}\end{array}$ \\
\hline Fan & $\begin{array}{l}\text { Power: } 80 \mathrm{~W} \text { (motor); Number of speed rates: } \\
\text { 2; Diameter: } 400 \mathrm{~mm} \text {; Number of blades: } 6 \text {; } \\
\text { Type of blade: curved }\end{array}$ \\
\hline Rotameter & $\begin{array}{l}\text { Make: Acrylic; Type: micro; Capacity: 0.6-6 } \\
\mathrm{m}^{3} / \mathrm{h}\end{array}$ \\
\hline $\begin{array}{l}\text { Anemo- } \\
\text { meter }\end{array}$ & $\begin{array}{l}\text { Model: AVM 06; Display: LCD; Make: BEE } \\
\text { Tech-Max; Show value: } 9999 ; \text { Accuracy: } \pm \\
(2.0 \% \text { reading }+50 \text { characters })\end{array}$ \\
\hline Hose & $\begin{array}{l}\text { Type: rubber; Length: } 1552.5 \mathrm{~mm} \text { (radiator to } \\
\text { tank: } 900 \mathrm{~mm} \text {, tank to pump: } 450 \mathrm{~mm} \text {, } \\
\text { rotameter to radiator: } 202.5 \mathrm{~mm} \text { ) }\end{array}$ \\
\hline
\end{tabular}

with increments of $0.12 \mathrm{~m}^{3} / \mathrm{h}$. The temperature of the cooling fluid at the inlet was varied from $40{ }^{\circ} \mathrm{C}$ to $75^{\circ} \mathrm{C}$. The thermocouple used to measure the temperature had an accuracy of $\pm 0.5^{\circ} \mathrm{C}$. A pump of $0.5 \mathrm{HP}$ was used to circulate the cooling fluid from the storage tank. An

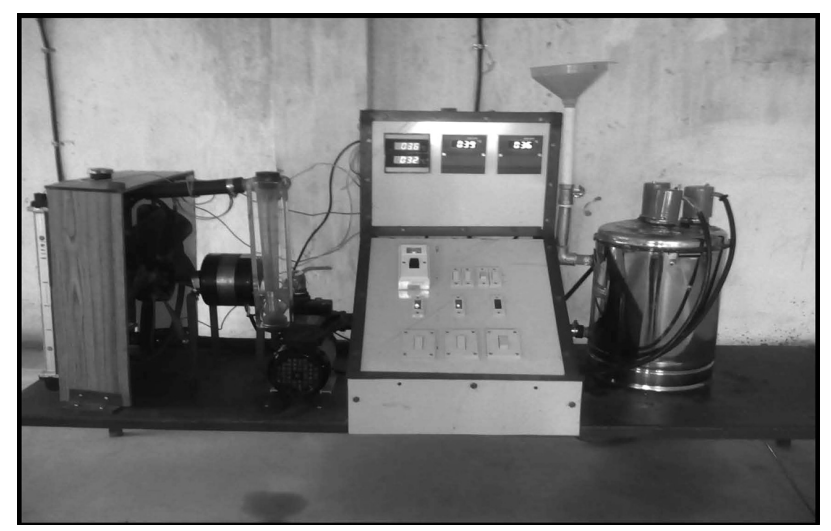

Figure 2: Experimental set-up photograph 
anemometer was used to measure the velocity of the air through the duct. Readings were taken at four points and the operating average velocity was calculated. Table 1 shows the specifications of the experimental set-up for this work.

\subsection{Experimental procedure}

The system was first cleaned thoroughly. Then the tank was filled with distilled water. A test run was done to ensure that the water circuit had no leakages. Then the heaters were switched on for the water to reach the required temperature. After that, the heating elements were controlled by the temperature controller to maintain a steady temperature. The water pump was switched on. After that, the radiator fan was switched on and we waited until steady-state conditions were reached and all the readings were taken. The temperatures at the outlet and inlet of the water and air were measured. The velocity of the air was also measured. The experiment was repeated for water-flow rates of $(0.72,0.84$ and $0.96) \mathrm{m}^{3} / \mathrm{h}$. For the second set of experiments, a mixture of water and ethylene glycol with a ratio of 1:1 was used. The experiments were then conducted using nanofluids with volume concentrations of $0.03-0.12 \%$, with increments of $0.03 \%$.

\subsection{Nanofluid characterization}

The characterization of nanofluids was done by evaluating the XRD test shown in Figures 3a and $\mathbf{3 b}$. The Sheerin formula was used to calculate the nanoparticle size, which was $40 \mathrm{~nm}$.
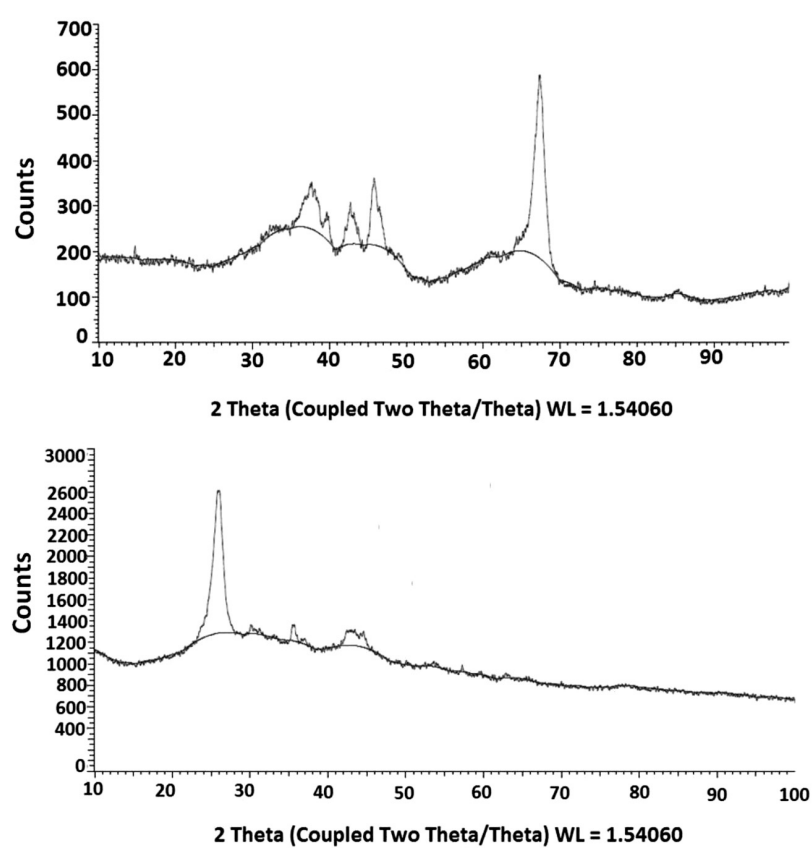

Figure 3: XRD test result for: a) $\mathrm{Al}_{2} \mathrm{O}_{3}$, b) MWCNT

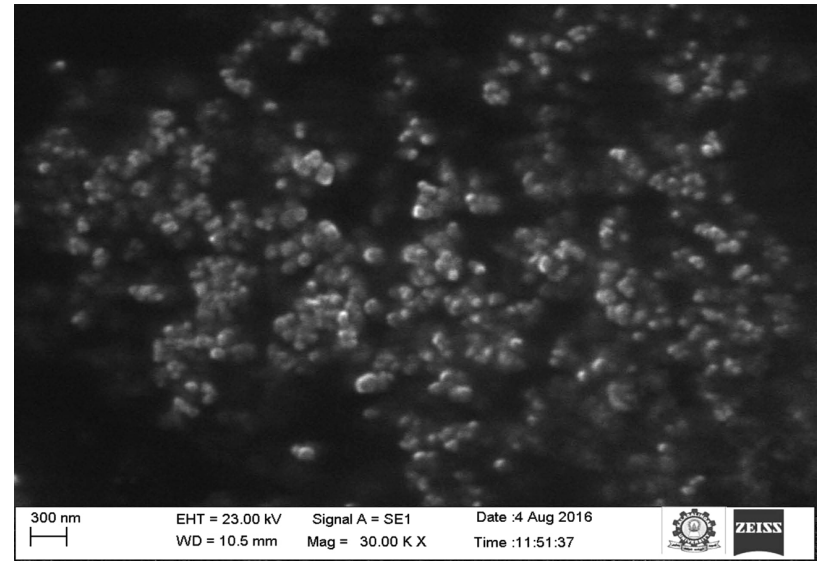

Figure 4: SEM test report for $\mathrm{Al}_{2} \mathrm{O}_{3}$

The precipitate formed was washed with distilled water and dried. SEM images of the prepared sample are shown in Figures $\mathbf{4}$ and 5. A nanofluid with the required volume concentration was then prepared by dispersing a specified amount of $\mathrm{Al}_{2} \mathrm{O}_{3}$ nanoparticles in water using an ultrasonic vibrator (Toshiba, India) generating ultrasonic pulses of $100 \mathrm{~W}$ at $36 \pm 3 \mathrm{kHz}$. To get a uniform dispersion and stable suspension, which determine the final properties of nanofluids, the nanofluids were kept under ultrasonic vibration continuously for $9 \mathrm{~h}$. No surfactant or $\mathrm{pH}$ changes were used as they may have some influence on the effective thermal conductivity of nanofluids. The $\mathrm{pH}$ values of the prepared nanofluids with different concentrations were measured and found to be around 5, which is far from the isoelectric point of 9.2 for alumina nanoparticles. This value, being far from the isoelectric point, ensures that the nanoparticles are well dispersed and the nanofluid is stable because of very large repulsive forces among the nanoparticles.

\subsection{Prepartion of $\mathrm{Al}_{2} \mathrm{O}_{3}$ /multi-walled carbon nanofluids}

The nanoparticles were purchased from Alfa Aesar, USA. The $\mathrm{Al}_{2} \mathrm{O}_{3}$ nanoparticle MWCNTs were tested with a Zetasizer machine for measuring the particle size,

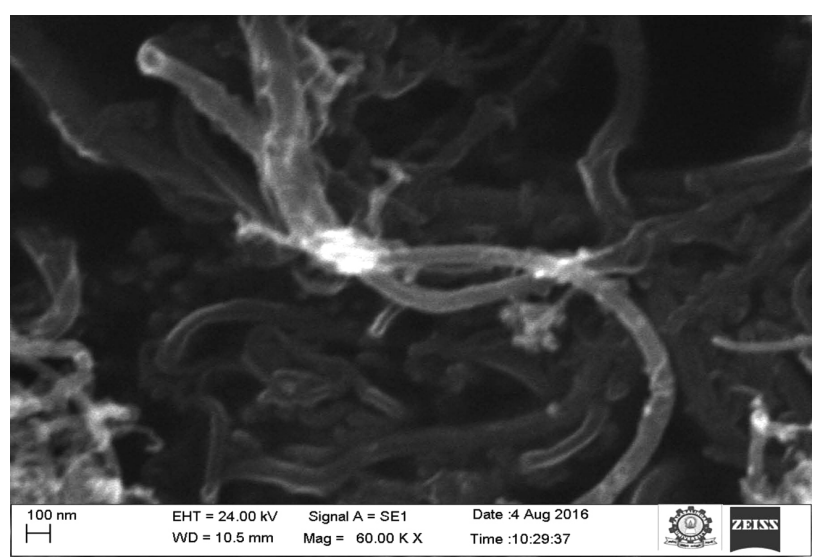

Figure 5: SEM image of MWCNT 


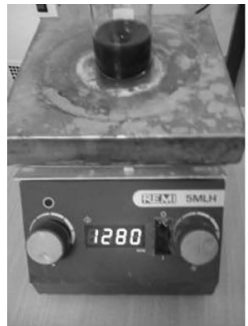

(a)

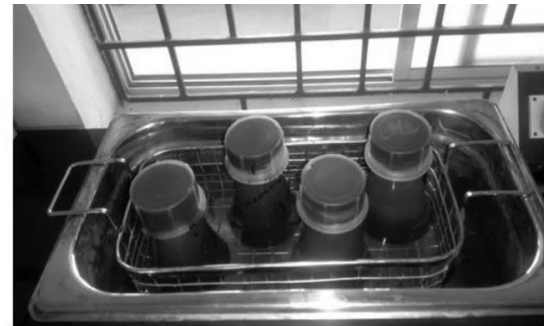

(b)
Figure 6: (a) Magnetic stirrer, (b) ultrasonicator

from Horibon, Japan. The machine is shown in Figure 6. The nanofluids were prepared as per volume concentration. Then a magnetic stirrer and an ultrasonicator were used to mix them without any sedimentation as shown below. The characteristics of aluminium are given in Table 2.

Table 2: Properties of the nanoparticles

\begin{tabular}{|c|l|c|c|}
\hline S. no. & \multicolumn{1}{|c|}{ Properties } & $\mathrm{Al}_{2} \mathrm{O}_{3}$ & MWCNT \\
\hline 1. & Purity $(\%)$ & 99.99 & 99.9 \\
\hline 2. & $\begin{array}{l}\text { Approximate } \\
\text { size }(\mathrm{nm})\end{array}$ & 50 & 60 \\
\hline 3. & Color & White & Black \\
\hline 4. & Morphology & Nearly spherical & Tubes \\
\hline 5. & Density $\left(\mathrm{g} / \mathrm{cm}^{3}\right)$ & 3.428 & 1.4 \\
\hline
\end{tabular}

Next, an ultra-violet (UV) test was carried out to check whether the nanofluids were without any sedimentation. No sediment was identified. Figure 7 clearly indicates that the nanofluids contained only the base fluid.

\section{RESULTS AND DISCUSSION}

Nanofluids with various volume concentrations were prepared. Then they were tested with the experimental set-up and the readings were taken. The thermal properties of various samples were tested and the results are shown below.

\subsection{Analysis of thermal properties}

\subsubsection{Measurement of viscosity values}

The viscosity of the nanofluids was measured using a Brookfield cone and plate viscometer (DV-E Viscometer), supplied by Brookfield Engineering Laboratories, USA, as shown in Figure 8. The device is

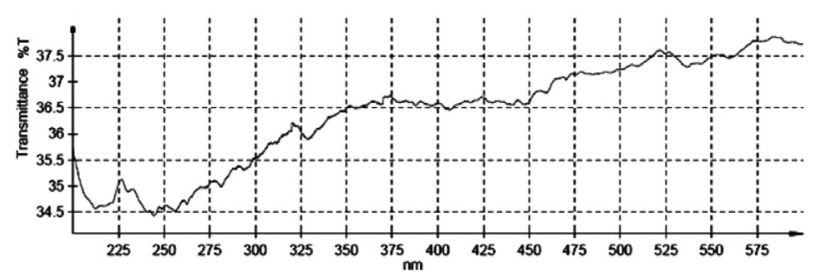

Figure 7: UV spectroscopy result

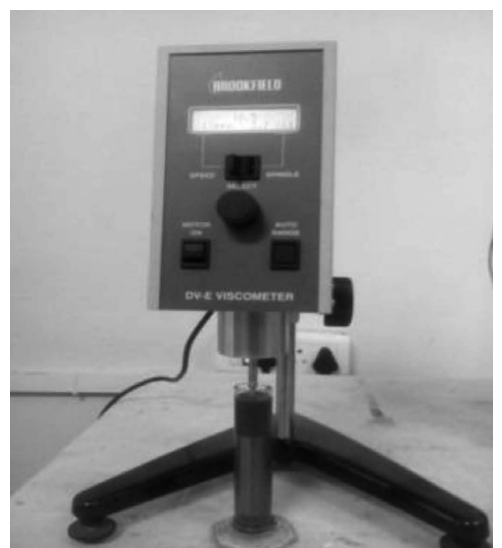

Figure 8: Viscometer

switched off before attaching the spindle. The spindle speeds available with this viscometer are in a range of $0-100 \mathrm{~min}^{-1}$ and the shear-rate range is $0-750 \mathrm{~s}$. Then the spindle is immersed in the center of the test material so that the fluid's level is at the immersion groove on the spindle's shaft. With a disc-type spindle, it is sometimes necessary to tilt the spindle slightly while immersing it to avoid trapping air bubbles on its surface. To make a viscosity measurement, a speed of $12 \mathrm{~min}^{-1}$ is selected. The maximum time allows the indicated reading to stabilize. The time required for its stabilization depends on the speed of the viscometer and the characteristics of the sample fluid. Now the device is switched off and the sample is replaced by a new one. A minimum of three measurements were made for each test sample. Then the average value was taken. Each sample constituted of a $20-\mathrm{ml}$ solution. Table 3 shows the values of the viscosity for all the samples.

Table 3: Viscosity values for the samples

\begin{tabular}{|c|l|c|}
\hline S. No. & \multicolumn{1}{|c|}{ Name of the sample } & Viscosity $(\mathrm{cP})$ \\
\hline 1. & $0.03 \%$ hybrid nanofluid & 23.5 \\
\hline 2. & $0.06 \%$ hybrid nanofluid & 20.5 \\
\hline 3. & $0.09 \%$ hybrid nanofluid & 22.5 \\
\hline 4. & $0.12 \%$ hybrid nanofluid & 20.5 \\
\hline 5. & EG+DW (1:1 ratio) & 18.5 \\
\hline 6. & DW & 1.5 \\
\hline
\end{tabular}

For the $0.03 \%$ sample, the thermal conductivity increases by $5 \%$ where the heat transfer at a higher temperature is considered to be the molecular-level difference of the sample. At the mean time for the $0.06 \%$ sample, the thermal conductivity increases by $11 \%$. It is concluded that with the increasing volume concentration of nanofluids, the heat transfer also increases. Thus, at the $0.12 \%$ volume concentration of nanofluids, a high heat-transfer rate is achieved. It is also concluded that with the hybrid nanofluids containing the base fluids, a high heat-transfer rate is achieved. With the increasing volume concentration of nanofluids, there is also a chance for pumping. This issue requires further research. 


\subsubsection{Thermal-conductivity measurement}

The compact KD2 Pro controller is much more than a simple readout for time and temperature as shown in Figure 9. A proprietary algorithm fits the time and temperature data with experimental integral functions using a nonlinear least squares method. This fully mathematical solution delivers thermal conductivity to within $\pm 10 \%$. The ASTM standard D5334 and IEEE standard 442-1981 are followed. All the samples were characterized at room temperature. The KD2 Pro was configured in the low-power mode with a 1-minute read time to prevent free convection in the fluid test samples. The accuracy of the KS-1 sensor and the associated KD-2 Pro unit was verified using the glycerol verification standard immediately before the measurements made on the test samples. A minimum of three measurements was made for each test sample. Before the beginning of each measurement, the vial with the material was vigorously shaken until all the nanoparticles were in the suspension and then the shaking continued for at least 60 additional seconds to ensure that the sample was well dispersed and fully suspended. The accuracy and range repeatability of this instrument are $\pm 1 \%$ and $\pm 0.2 \%$, respectively. The thermal conductivity of all six samples measured using a $0.40 \mathrm{~mL}$ solution for each sample is shown in Table 4.

Table 4: Thermal-conductivity values for the samples

\begin{tabular}{|c|c|c|c|}
\hline S. no & Name of the sample & $\begin{array}{c}\text { Temperature } \\
\left({ }^{\circ} \mathrm{C}\right)\end{array}$ & $\begin{array}{c}\text { Thermal } \\
\text { conductivity } \\
(\mathrm{W} / \mathrm{mK})\end{array}$ \\
\hline 1. & $0.03 \%$ hybrid nanofluid & 28.75 & 0.579 \\
\hline 2. & $0.06 \%$ hybrid nanofluid & 28.72 & 0.551 \\
\hline 3. & $0.09 \%$ hybrid nanofluid & 28.68 & 0.585 \\
\hline 4. & $0.12 \%$ hybrid nanofluid & 29.19 & 0.570 \\
\hline 5. & EG+DW $(1: 1$ ratio $)$ & 28.7 & 0.569 \\
\hline 6. & DW & 29.04 & 0.529 \\
\hline
\end{tabular}

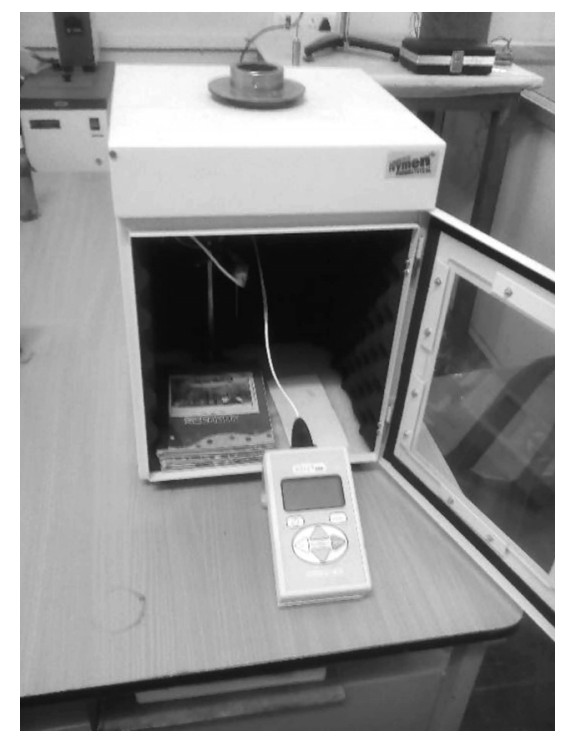

Figure 9: Thermal-conductivity instrument

\subsection{Uncertainity analysis}

Experimental uncertainties were calculated using the method developed by Kline and McClintock. This method incorporates the estimated uncertainties of the experimental measurements such as the water-inlet temperature, water-outlet temperature and water-mass-flow rate in the experiment. These are then compared with the final parameters of the heat-transfer rate and the calculated Reynolds number. Using the measured uncertainties of the above-mentioned parameters, the maximum calculated uncertainties for the heat-transfer rate were found to be $10 \%$ and $9.7 \%$ for pure water and the nanofluids, respectively. The fluid-mass-flow rate participated significantly to the calculated uncertainty, especially in the case of the nanofluids. The maximum uncertainty of the calculated Reynolds number was found to be $2.8 \%$ for all the cases.

\subsection{Computational-fulid-dynamics analysis (CFD)}

The heat transfer rate was also measured using the computational-fluid-dynamics (CFD) software. Its results were also compared with the experimental results. It is shown that the results for the increasing heat transfer in the experimental set-up were higher than those of the CFD analysis. In Figure 10, for the $0.09 \% \mathrm{Al}_{2} \mathrm{O}_{3}+1 \%$ MWNCT nanofluid, the CFD analysis shows that a small increment in the heat-transfer rate of $19 \mathrm{~kW}$ is obtained at the given mass-flow rate $\left(0.6 \mathrm{~m}^{3} / \mathrm{hr}\right)$ and the temperature of $40{ }^{\circ} \mathrm{C}$. For the temperature of $70{ }^{\circ} \mathrm{C}$ and the $0.96 \mathrm{~m}^{3} / \mathrm{h}$ mass-flow rate, the maximum heat-transfer rate of $56 \mathrm{~kW}$ is obtained with the CFD analysis. It is observed that while adding $1 \%$ MWNCT with the $\mathrm{Al}_{2} \mathrm{O}_{3}$ nanofluids, the heat-transfer rate increases by $26 \%$ according to the CFD analysis.

Figure 11 shows the heat-transfer rate at the $0.6 \mathrm{~m}^{3} / \mathrm{h}$ mass-flow rate for pure distilled water, $1 \% \mathrm{MWNCT}$ and $1.5 \%$ MWNCT with distilled water, $0.09 \% \mathrm{Al}_{2} \mathrm{O}_{3}$ nanofluids with $1 \%$ MWNCT and $1.5 \%$ MWNCT. From this graph, it is clear that the heat-transfer rate of the $0.09 \% \mathrm{Al}_{2} \mathrm{O}_{3}$ nanofluid is followed by those of $1 \%$

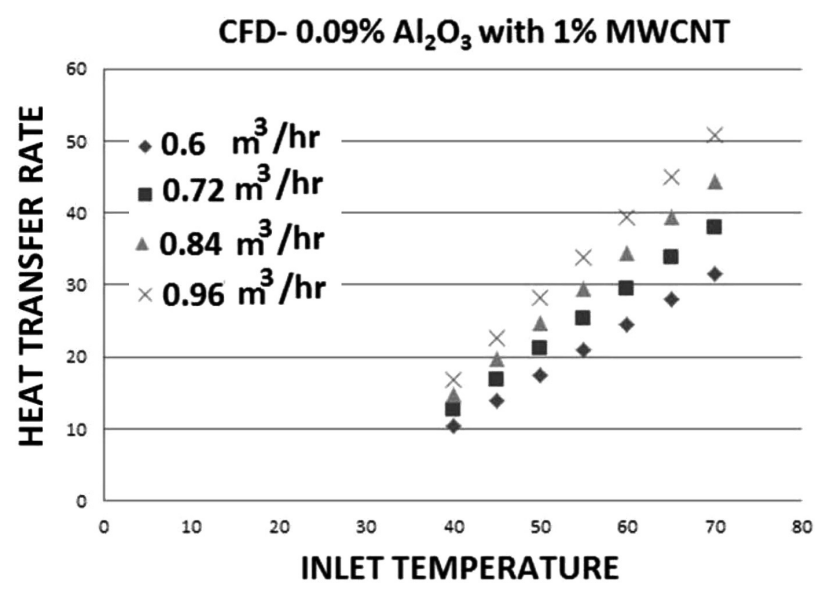

Figure 10: CFD analysis for $0.09 \% \mathrm{Al}_{2} \mathrm{O}_{3}$ with $1 \%$ MWCNT 


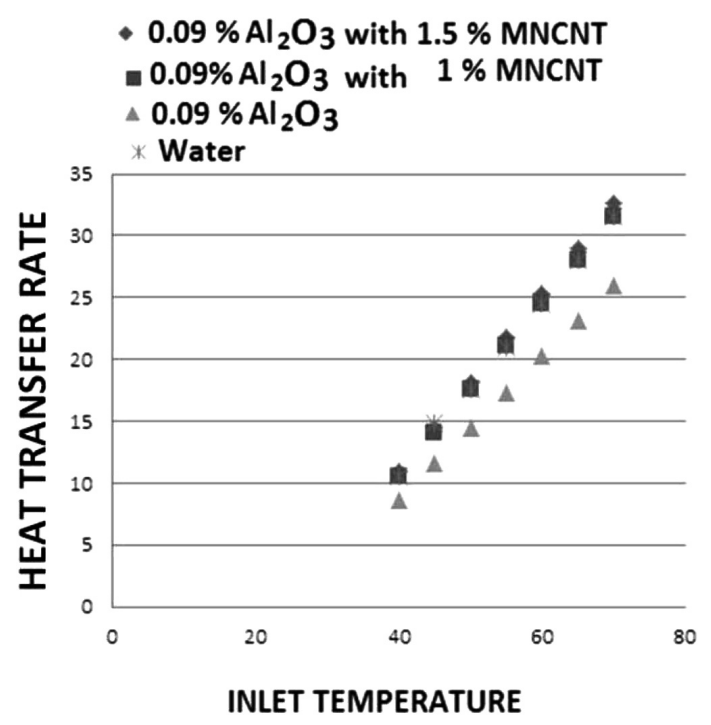

Figure 11: Experimental comparison of the heat-transfer rate for various percentages of $\mathrm{MNCNT}, \mathrm{Al}_{2} \mathrm{O}_{3}$ and water $\left(0.6 \mathrm{~m}^{3} / \mathrm{h}\right)$

MWNCT and $1.5 \%$ MWNCT. While considering the comparison with the CFD analysis, we observe a high heat-transfer rate.

\section{CONCLUSIONS}

Experimental and CFD analyses were done. The MWCNT was added together with $0.09 \% \mathrm{Al}_{2} \mathrm{O}_{3}$ nanofluids. The input temperature varied between $(40,45,50$, $55,60,65$ and 70$){ }^{\circ} \mathrm{C}$. The mass-flow rate varied between $(0.6,0.72,0.84$ and 0.96$) \mathrm{m}^{3} / \mathrm{h}$, respectively. It was concluded that when adding $(0.5,1$ and 1.5$) \%$ MWCNT together with the nanofluids, increased heat-transfer rates were obtained. According to the CFD analysis, with the $0.5 \% \mathrm{MWCNT}+0.09 \% \mathrm{Al}_{2} \mathrm{O}_{3}$ nanofluid, the heattransfer rate increased by $3.31 \%$; with $1 \%$ MWCNT + $0.09 \% \mathrm{Al}_{2} \mathrm{O}_{3}$, the heat-transfer rate increased by $8.96 \%$; and, similarly, when $1.5 \%$ MWCNT was added together with the $\mathrm{Al}_{2} \mathrm{O}_{3}$ nanofluid, an increase in the heat-transfer rate of $13.814 \%$ was obtained. In the case of the experimental analysis, when adding $0.5 \%$ MWCNT together with the $0.09 \% \mathrm{Al}_{2} \mathrm{O}_{3}$ nanofluids, the maximum increase in the heat transfer rate of $16 \%$ was obtained at a massflow rate of $0.96 \mathrm{~m}^{3} / \mathrm{h}$. With the addition of $1 \%$
MWCNT and $0.09 \% \mathrm{Al}_{2} \mathrm{O}_{3}$ nanofluid, the heat-transfer rate increased by $34 \%$. Similarly, for $1.5 \%$ MWCNT and $0.09 \% \mathrm{Al}_{2} \mathrm{O}_{3}$ nanofluid, the heat-transfer rate increased by $35 \%$. It was proven that MWCNT significantly improved the heat transfer when added together with the $\mathrm{Al}_{2} \mathrm{O}_{3}$ nanofluids.

\section{REFERENCES}

${ }^{1}$ K. S. Suganthi, V. Leela Vinodhan, K. S. Rajan, ZnO-Propylene Glycol-Water Nanofluids with Improved Properties for Potential Applications in Renewable Energy and Thermal Management, Colloids and Surfaces A: Physicochemical and Engineering Aspects, 506 (2016) 5, 63-73, doi:10.1016/j.colsurfa.2016.06.007

${ }^{2}$ B. Ilhan, M. Kurt, H. Ertürk, Experimental investigation of heat transfer enhancement and viscosity change of hBN nanofluids, Experimental Thermal and Fluid Science, 77 (2016), 272-283, doi:10.1016/j.expthermflusci.2016.04.024

${ }^{3}$ M. A. A Behabadi, M. Shahidi, M. R. Aligoodarz, M. Fakoor, An experimental investigation on rheological properties and heat transfer performance of MWCNT-water nanofluid flow inside vertical tubes, Applied Thermal Engineering, 106 (2016) 5, 916-924, doi:10.1016/j.applthermaleng.2016.06.076

${ }^{4}$ W. H. Azmi, K. Abdul Hamid, N. A. Usri, R. Mamat, K. V. Sharma, Heat transfer augmentation of ethylene glycol: water nanofluids and applications - A review, International Communications in Heat and Mass Transfer, 75 (2016), 13-23, doi:10.1016/j.icheatmasstransfer. 2016.03.018

${ }^{5}$ M. B. Bigdeli, M. Fasano, A. Cardellini, E. Chiavazzo, P. Asinari, A review on the heat and mass transfer phenomena in nanofluid coolants with special focus on automotive applications, 60 (2016), 1615-1633, doi:10.1016/j.rser.2016.03.027

${ }^{6}$ M. Tamizi, M. Kamalv, M. Namazian, Dependency of the thermophysical properties of nanofluids on the excess adsorption, International Journal of Heat and Mass Transfer, 99 (2016), 630-637, doi:10.1016/j.ijheatmasstransfer.2016.04.029

${ }^{7}$ S. Suresh, K. P. Venkitaraj, P. Selvakumar, M. Chandrasekar, Effect of $\mathrm{Al}_{2} \mathrm{O}_{3}-\mathrm{Cu}$ /water hybrid nanofluid in heat transfer, Experimental Thermal and Fluid Science, 38 (2012), 54-60, doi:10.1016/ j.expthermflusci.2011.11.007

${ }^{8}$ D. Madhesh, S. Kalaiselvam, Experimental Analysis of Hybrid Nanofluid as a Coolant, Procedia Engineering, 97 (2014), 1667-1675, doi:10.1016/j.proeng.2014.12.317

${ }^{9}$ N. Bozorgan, K. Krishnakumar, N. Bozorganv, The Performance Evaluation of Overall Heat Transfer and Pumping Power of $\gamma-\mathrm{Al}_{2} \mathrm{O}_{3} /$ water Nanofluid as Coolant in Automotive Diesel Engine Radiator, Analele Universitălii "Eftimie Murgu" Resita, 1 (2013)

${ }^{10}$ G. Huminic, A. Huminic, Application of nanofluids in heat exchangers: A review, Renewable and Sustainable Energy Reviews, 16 (2012) 8, 5625-5638, doi:10.1016/j.rser.2012.05.023 